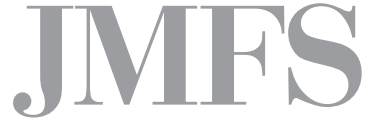

Journal of Management and Financial Sciences
Volume XI

Issue 34 (November 2018)

pp. 51-75

Warsaw School of Economics

Collegium of Management and Finance

Pawet Wnuczak

Department of Finance

Kozminski University

\title{
Voluntary liquidation: When is it financially profitable?
}

\begin{abstract}
The aim of this article is to offer insight into a concept making it possible to assess the financial rationality of the voluntary liquidation of businesses. The author of the study presents a decision-making algorithm that should be applied before deciding to voluntarily liquidate a business entity. The algorithm is based on the concept of Value Based Management (VBM), and the related calculations have been performed following the basic rules of mathematical finance. The presented solution is also based on the calculation of free cash flow generated by an enterprise for its owners and on investigating the relationship between the said cash flow and the rate of return expected to be attained by the enterprise's owners. Because no such models are given or discussed in the literature covering the subject matter, it appears that the proposed solution may become a valuable tool to improve the process of making a decision in the scope of voluntary liquidation of an enterprise.
\end{abstract}

Keywords: liquidation, bankruptcy, merger, acquisition

JEL Classification Codes: G33 


\section{Introduction}

The literature devoted to the subject matter in question discusses various ways an enterprise can choose to pursue its exit from the market. The most common solutions are bankruptcy, merger with or acquisition by a different entity, or voluntary liquidation [Amendola et al., 2015, pp. 33-41]. There are many different factors determining the way a given firm exits the market [Harhoff et al., 1998, pp. 453-488; Schary, 1991, pp. 339-353].

A bankruptcy proceeding is initiated when a firm becomes insolvent. Considering the form of such proceedings and the direct and indirect court fees [Altman, 1984, pp. 1067-1089; Couwenberg and de Jong, 2008, pp. 105-127], it is the least cost-effective and the least profitable way a firm may exit the market [Balcaen et al., 2012, pp. 949-975]. A merger or acquisition (M\&A) means that the firm is liquidated by way of being sold to a different entity. Voluntary liquidation occurs when all assets of a firm are sold, all obligations towards creditors are satisfied, and all remaining capital is distributed to the owners [Ghosh et al., 1991, pp. 773-789; Kim and Schatzberg, 1987, pp. 311-328; Sullivan et al., 1997, pp. 3-18]. Both liquidation through merger and acquisition (M\&A) and voluntary liquidation are possible when the value of the liquidated assets minus the liquidation costs exceeds the value of the firm's liabilities - in such a situation it is still possible to pay all obligations towards creditors [Kim and Schatzberg, 1987, pp. 311-328].

The reference literature focuses on several areas related to company liquidation. Among these areas, there are determinants of various ways to exit the market [Hunsaker, 1999, pp. 9-24; Balcaen et al., 2012, pp. 949-975; Amendola et al., 2015, pp. 33-41], typical qualities of liquidated firms [Ghosh et al., 1991, pp. 773-789; Poletti-Hughesa and Ozkanb, 2014, pp. 36-50], the impact of the information about an intended liquidation of a firm on the price of the firm's stocks [Kim and Schatzberg, 1987, pp. 311-328; Ervin and McConnell, 1997, pp. 325-354] and influence of a crisis on the firm's liquidation [Mierzejewska, 2014, pp. 35-48; Romanowska, 2014, pp. 13-23]. Moreover, the discussion also covers models applied to forecast the risk of bankruptcy [Altman, 1968, pp. 589-609; Altman, 1984, pp. 1067-1089; Scott, 1981, pp. 317-344; Jones, 1987, pp. 131-164]. According to the author's knowledge, however, the literature does not offer a standardized and systematized approach to the issue of assessment of the financial reasonability of voluntary liquidation. In other words, there are no models or decision-making schemas making it possible to assess the rationality of the liquidation of a firm from a financial perspective. Meanwhile, this topic seems to be of great significance. Voluntary liquidation may be a good answer to deteriorating results of a firm; it may be a measure to enable a firm to transfer its liquidated capital and use it in a more profitable way; it may also help the owners of a liquidated firm gain some tax-related benefits [Sullivan et al., 1997, pp. 3-18]. The subject matter becomes even more noteworthy given the fact that company owners, often attached emotionally to the firm, may fail to see the financial reasonability behind voluntary liquidation if no appropriate tools are applied. 
This article, therefore, contributes to the existing literature in three ways. First, I present a coherent and easily applicable model, making it possible to take a conscious and rational decision in the scope of subjecting a firm to voluntary liquidation. The article offers a decision-making path that should precede the actual decision to liquidate the firm. It is important to notice that the implementation of the presented approach should help enterprise owners use the available capital effectively, which makes it useful from both economic and social perspectives. Second, the article points to a need for assessment of the reasonability of conducting a business on the basis of a comparative analysis of the obtained and expected rates of return on the capital invested in a given firm. In the literature devoted to the subject, the issue of company liquidation is brought to the surface mainly in the context of financial problems and trouble with the payment of liabilities. Third, the article includes a review of the literature and research areas addressing the subject of company liquidation.

The remaining parts of the paper are organized as follows. In section 2, I present a review of the literature devoted to company liquidation, covering the models supporting pro-liquidation decisions in more detail. In subsection 3, I present a model making it possible to assess the financial rationality of a decision to liquidate a firm. The last chapter features conclusions regarding the presented solutions.

\section{Literature on company liquidation}

\subsection{Empirical studies on company liquidation}

Studies concerning company liquidation focus on many aspects related to business entities leaving the market. One of these aspects concerns determinants of the ways to effect liquidation (bankruptcy, merger, or voluntary liquidation) of firms struggling financially. A broad range of studies in this scope has been conducted by S. Balcaen et al. [2012]. By applying logits, they analyzed 6,118 cases of liquidation of firms operating in Belgium. A total of $41 \%$ of firms included in the study were liquidated by exit through a court in the form of a forced exit from the market (concerning mostly bankruptcies), 44\% of them subjected themselves voluntarily to liquidation, and $14 \%$ of them were liquidated by way of merger with or acquisition by another entity. The results of the study show that voluntary liquidation is more probable than bankruptcy in the case of firms that possess larger resources of cash, are less indebted, and do not have a debt secured by means of other assets. A similar study concerning the impact of various factors (i.e., microeconomic, typical qualities of firms) on the ways of leaving the market (bankruptcy, merger, voluntary liquidation) was conducted by A. Amendola [2015] on the basis of the data about firms operating in the Italian market. Among other researchers following the abovementioned research trend are, e.g., Pastena and Ruland [1986], Peel and Wilson [1989], and Kanatas and Qi [2004]. 
Another liquidation-related aspect analyzed in the literature devoted to the subject in question is the time of liquidation of a given firm. S. Balcaen et al. [2011] analyzed the time passing from the moment of appearance of signals indicating a given firm is in a difficult situation to the moment this firm actually exits the market. The study was conducted among 5,233 Belgian businesses. The results show that a relatively high level of resources (expressed mainly in a relatively large amount of cash at disposal) extends the time of exit through court. However, the large amount of such resources leads to a shortening of the duration of voluntary liquidation. According to the authors of the study, the relatively shorter time of voluntary liquidation may be explained by a greater motivation of the firm's owners to protect the firm's assets against further losses. Moreover, the literature devoted to the subject matter features studies concentrating on the period of time during which firms operate on the basis of Chapter 11 of the United States Bankruptcy Code - Reorganization procedures [Bandopadhyaya, 1994, pp. 346-350; Li, 1999, pp. 305-312; Orbe et al., 2001, pp. 35-42; Denis and Rodgers, 2007, pp. 101-118].

The findings of many studies on liquidation indicate that announcements of company liquidation are accompanied by an increase in the stock price. Kim and Schatzberg [1987] conducted a study on 73 entities liquidated in the period 1963-82. According to the findings of their study, an announcement of a pro-liquidation decision generates (within three days of the announcement) an abnormal rate of return on a stock of a liquidated firm on the level of $14 \%$, and another $3 \%$ after the owners of the firm confirm its liquidation. Similar findings were arrived at by Hite et al. [1987], who examined 49 partial liquidations announced in the period 1962-84, and by Skanz and Marchesini [1987], who conducted an analysis of 37 entities liquidated in 1970-82.

Sullivan et al. [1997] conducted an analysis of motivators pushing company owners to liquidate their business. Among the discovered reasons for liquidation, there were financial problems, a conflict of interest between company owners and managers (agency conflict), and a desire to gain tax benefits. Like in the case of other studies of such type, it was found that announcements of company liquidation were followed by abnormal rates of return $(9.19 \%$ within two days of the announcement, and $16.56 \%$ after 31 days of the announcement). According to the expectations of the authors of the study, the owners of those liquidated firms that were in the poorest financial situation gained the highest rates of return. As part of the study, the impact of the conflict of interest on the said rates of return was also analyzed. The authors believed that according to the theory of agency conflict, managers could conduct the process of company liquidation not fully in line with the best interest of its owners (e.g., such an issue may occur when a manager liquidating a firm maintains the relationship with the party acquiring the liquidated assets) or could liquidate a firm even if it is actually against the interest of the owners of that firm (i.e., such a solution is not most profitable from their perspective). In such cases, it was expected that the rates of return induced by announcements of liquidation would be relatively lower. However, the results of the conducted study did not prove the relationship to be valid. Moreover, it was not proven that company liquidation could be 
motivated by the aforesaid conflict of interest. At the same time, the obtained results make it possible to positively validate the hypothesis according to which managers negotiate more advantageous conditions of liquidation if they also own the liquidated assets. Additionally, the study did not confirm that company liquidation could be a way to transfer assets and to gain any related tax benefits - but the authors stress it might be because of legal changes; the provisions in force before 1987 could have, in certain conditions, encouraged company liquidation (the study was conducted after the applicable law was changed).

The subject-related literature covers studies concerning typical qualities of firms whose owners decided to opt for voluntary liquidation. Ghosh et al. [1991] analyzed the operational and financial qualities of firms that underwent the process of voluntary liquidation. The sample included 49 firms that announced voluntary liquidation in the period between 1962 and 1984 . The study involved comparing liquidated and non-liquidated firms operating in the same business sectors. The findings showed that in the case of the liquidated firms, there were drops in sales, attempts of takeover in past periods, and an increased presence of the owners on these firms' boards (compared to the non-liquidated firms). However, no differences in the values of $\mathrm{P} / \mathrm{E}$ indicators and in the level of debt were found in the two groups of entities subject to the analysis. An analysis of the qualities of 61 stock-listed firms that underwent voluntary liquidation in the period between 1970 and 1980 was also conducted by G. Ervin and J. McConnell [1997]. Their findings revealed that the liquidated firms - compared to the non-liquidated ones - featured a lower Tobin's Q, a higher share of equity owned by the persons managing a given entity, and more frequent attempts of taking over the control of a given firm in periods preceding liquidation.

\subsection{A theoretical presentation of company liquidation in the reference literature}

The reference literature covers the models applied to predict financial problems of businesses to a large extent [Altman, 1968, pp. 589-609; Altman, 1984, pp. 1067-1089; Scott, 1981, pp. 317-344; Jones, 1987, pp. 131-164; Delaney, 1991; Jones and Hensher, 2007, pp. 89-107]. However, there are no studies presenting models that allow one to assess the financial reasonability of continuation of business and indicate the circumstances where a given firm should undergo voluntary liquidation. One such model was offered by M. Schary [1991], who studied the determinants of company liquidation. For the needs of the study, she developed a formula describing a situation where company owners opt for voluntary liquidation. According to her concept, the owners decide to liquidate their firm if the value of continuation of operating the business assumes a value lower than zero. This value is described as follows:

$$
\mathrm{Y}=\left(\mathrm{P}_{\mathrm{t}}-\mathrm{M}_{\mathrm{t}}\right)-\left(\mathrm{S}_{\mathrm{t}}-\mathrm{F}_{\mathrm{t}}\right)
$$

where:

$\mathrm{Y}$ - excess of continuation value over the liquidation value from the owner's perspective (value of continuation of business operation); 
$\mathrm{P}_{\mathrm{t}}$ - company value assuming its business operation is continued;

$\mathrm{M}_{\mathrm{t}}$ - debt value assuming the firm continues its business operation (usually debt market value); $\mathrm{S}_{\mathrm{t}}$ - liquidation value of the firm;

$\mathrm{F}_{\mathrm{t}}$ - debt value assuming the firm is liquidated (usually debt liquidation value).

The abovementioned approach is similar to some extent to that presented in this study - both concepts are based on determining the current company value. However, M. Schary [1991] seems to ignore the issue of dependence between company value (for the variant of continuation of business) and the rate of return expected by the owners adopted in the analysis. Meanwhile, it is of crucial importance to the act of making a decision for company liquidation'. Furthermore, the said solution does not concern the issue of actions that the company owners may possibly take before they decide to liquidate the firm, nor does it consider the problem of the availability of various alternatives of utilization of the capital gained from liquidation. M. Schary does not present a decision-making path that should precede the actual decision to liquidate a given business entity. It seems that it is possible to offer a concept that does consider the issues omitted in Schary's model.

Another approach making it possible to assess the financial reasonability behind continuation of a given business was developed by Chen et al. in 1995. Based on earlier studies by, e.g., Altman [1993], Berkovitch and Kim [1990], Jensen and Meckling [1976], John [1993], and Myers [1977], they developed a new model composed of a system of equations where the obtained results made it possible to assess the financial rationality of investing in value-creating opportunities. The model considers the perspective of both owners and creditors. It makes it possible to assess the financial rationality of an investment in opportunities making it possible for a firm to survive on the market (from the perspective of all capital providers) and helps one evaluate the circumstances in which credit providers are not interested in further financing of a given firm - and when the best option is to liquidate such a firm. The concept is based on NPV technique, as part of which two scenarios are analyzed: one assuming a pessimistic variant and another assuming a positive turn of events. Each of the variants is assigned a 50\% likelihood of occurrence. It is important to stress the fact that the presented model can be applied only in the case of entities that are in a difficult financial situation. Such a situation has been defined as one where the liquidation value of a firm's assets is lower than the nominal value of the firm's liabilities towards its creditors. Moreover, the proposed solution focuses on the assessment of new investments whose pursuit may let the firm survive in the market. The model proposed in this paper offers a solution covering a full range of business operations (not only new projects). In addition to that, Chen et al. [1995] do not present a decision-making scheme related to the process of voluntary liquidation.

The theoretical aspects concerning the issue of financial reasonability of enterprise liquidation are also pointed out by Zarzecki [1999]. He stresses that operating a business with

1 According to income-based methods of valuation, company value is determined, among other factors, by the value of the expected rates of return. 
the present value cash flow lower than the enterprise liquidation value will lead to a destruction of the existing value - one attainable by means of liquidating assets. In such a situation, not making a decision for enterprise liquidation equals an approval of value destruction and is an act that is highly irrational and much against the interests of owners [Zarzecki, 1999, pp. 47-48]. A similar point of view as for the reasonability of business liquidation procedure is shared by Higgins [1995]. None of the works in question offer a method of calculation of liquidation value, and this value may depend on the adopted value standard (meaning the nature of the transaction and the parties involved). Besides, in reality, a company liquidation following the presented conditions will not always be the most profitable solution from the owner's point of view (e.g. the owner may lower their expectations regarding the flows generated by the company, which will lead to an increase in the present value of the flows generated by the company above the liquidation value).

The moment when liquidation of an enterprise becomes reasonable may also be considered from the perspective of bankruptcy codes. Many of such codes come with positive net-worth agreements, included in an overt or covert manner. This gives creditors the right to force a liquidation or reorganization procedure when the value of assets falls becomes lower than a given level determined earlier [Galai et al., 2007, pp. 3604-3620]. There are works devoted to capital structure and securities valuation, which suggest that liquidation takes place only when the value of assets of a given enterprise has reached the distress threshold and stayed below this threshold for an extended period of time [Fan and Sundaresan, 2000, pp. 1057-1099; Francois and Morellec, 2004, pp. 387-411].

The issue of determining a firm's liquidation value, which has a direct effect on the decision on continuing or abandoning the business, is not discussed very widely in the reference literature [Poborský, 2015, pp. 386-393]. Business valuation methodology focuses mostly on the income approach, and especially on the discounted cash-flow method (DCF), which has been given a lot of attention, analysis, and coverage in theoretical works so far [Poborský, 2015, pp. 386-393]. Poborský [2015] notices that the literature devoted to business valuation fails to take the most essential problematic areas regarding liquidation valuation into account, i.e. how the valuer should plan the debt repayment schedule, which laws must be considered, how the transaction costs should be assessed, or how the discount factor should be determined. Liquidation value itself is usually determined as the difference between the market value of property minus the value of debt [Damodaran, 2006, pp. 497-540]. References highlight also the necessity to take the transaction costs into account in the process of valuation of the liquidation value [Damodaran, 2006, pp. 497-540; Mandl and Rabel, 1997]. Their amount depends on the specificity of the valued assets, and the more unique they are, the bigger they become [Damodaran, 2006, pp. 497-540]. When determining the liquidation value, it is also important to consider the relevant laws and regulations, with a particular emphasis on the tax law, as they all affect the process of valuation of liquidation value [Poborský, 2015, pp. 386-393]. Detailed guidelines regarding the scope of liquidation value determination have been offered by Wollny [2010]. The main aspect he stresses is that if the liquidation value is greater than the result of 
a valuation based on the income approach (i.e. based on the going-concern principle) and if liquidation is an option considered, it is necessary to use liquidation value. He also adds that liquidation value should be used to value an enterprise when the future operation of such an enterprise depends on people who manage the enterprise and who plan to leave it. The most important principles of liquidation valuation defined by Wollny [2010] include: a necessity to exclude some assets from calculation (e.g. reserves), a need to consider the costs of sale of assets, inclusion of taxes related to the process of property liquidation in the valuation, valuation of the present value of assets, application of a model different than CAPM to calculate the discount rate (because of the fact that the risk concerning a business in liquidation differs from the ongoing business). In the context of determination of liquidation value, Burgstahler and Dichev [1997] speak of the necessity to establish company adaptation value, which should take alternate ways of utilization of assets into consideration. Therefore, the actual liquidation value includes the price at which assets can be sold at a given time. But it should also take into account the possibility of such relocation of assets that would make it possible to generate cash flows at a level which company owners find at least satisfactory.

When discussing the issues related to liquidation value determination, it is necessary to mention the adaptation of the concept of value to the circumstances accompanying the process, determined by the purposes of valuation and the scope of use of its outcomes. This has given birth to two main trends of valuation considered in such a way. These trends are: the German functional school and the Anglo-Saxon school. The Anglo-Saxon school of valuation is related directly to the creation of diverse standards for values and enterprises in Anglo-Saxon countries. The idea refers to a definition of a value type highlighted from the point of view of the party whose perspective forms the basis for valuation of a given value, and therefore determines the factors and the circumstances of valuation that have to be all taken into account [Zarzecki and Grudziński, 2010, pp. 429-437]. We can usually speak of four key value standards: fair market value, fair value, investment value, and intrinsic value [Pratt, 1989, pp. 4-12]. The functional school of valuation points to the need for carrying out a valuation in the context of specific purposes (e.g. sale and purchase transactions, company restructuring processes) and functions, meaning needs and expectations of the valuation's addressees each time [Matschke et al., 2010, pp. 1-39; Matschke and Brösel, 2011, pp. 5-53]. The functional approach to company valuation, bearing in mind that valuation may serve different purposes and address the needs of a broad range of stakeholders, makes it possible to arrive at results that fulfil the expectations of all of the directly interested parties. Such an approach has given rise to the functionally oriented concept of company value, which has enriched the theory and practice with such notions as: decision value, argumentation value, and arbitrary value [Matschke et al., 2010, pp. 1-39; Jaki, 2012, pp. 553-560]. Taking the above discussion on the reasonability of company liquidation, it is necessary to take into account the perspectives of the parties that are included in the scope of such an analysis.

To summarize, the literature devoted to the subject matter in question focuses on determinants of company liquidation. The issue of models making it possible to ascertain 
whether voluntary liquidation of a firm is financially reasonable and when such solution is financially reasonable has been covered to a relatively limited extent. Moreover, it seems that the presented models may be improved from a practical point of view. Taking the above into account, the author of the study has presented his own concept of the assessment of the rationality of voluntary liquidation of firms.

\section{When is voluntary liquidation profitable - a model}

According to the concept of value-based management, the basic aim of a firm's operation in the market is to maximize its value for its owners (shareholders) [Rappaport, 1986, pp. 3-11; Stewart, 1991 pp. 1-68; Copeland et al., 1990, pp. 3-49]. As argued by A. Rappaport [1986], concentrating on long-term cash flows is the essence of the model of the policy of increasing shareholder value. The value of such cash flows should let the owners of a given firm gain the expected rate of return from the capital they have employed. A further part of the study features a presentation of the possible decisions to be made by a firm's owner when the cash flows gained from the pursued business are too low to cover the expected rate of return on the invested capital. Moreover, I will also describe the circumstances in which the continuation of business is financially unprofitable.

Analysis of the issue of achievement of the owner-expected rate of return on the capital employed requires application of common income-based methods of valuation. According to these methods, enterprise value reflects a given enterprise's ability to generate free cash flows to the owners [Mielcarz and Wnuczak, 2011, pp. 44-57]. The model of discounted cash flows, used in enterprise valuation, is based on several equivalent methods [Wnuczak and Mielcarz, 2009, pp. 275-287]. Considering the practice of enterprise valuation and the theory of finance, two of the said methods seem to be of particular significance [Fernández, 2007, pp. 853-876; Nel, 2009, pp. 117-135]: the FCFF (Free Cash Flow to Firm) and the FECF (Free Cash Flow to Equity). Among other methods, there are also Economic Value Added (EVA) [Stewart, 1990 pp. 118-178; Shil, 2009 pp. 169-177; Wnuczak, 2011, pp. 505-516] and Adjusted Present Value (APV) [Myers, 1974, pp. 1-25].

To check whether the cash flows gained by owners meet their expectations in terms of the rate of return on the capital employed (BV), it is first necessary to valuate a given enterprise. According to the model of discounted cash flow, the formula making it possible to establish the value of an enterprise from the perspective of its owners (equity) is as follows [Plenborg, 2002, pp. 303-318]2:

$$
E=\sum_{t=1}^{\infty} \frac{F C F E_{t}}{\left(1+r_{e}\right)^{t}}
$$

(formula 1)

2 The decision was to apply the FCFE method (free cash flow to equity) because the approach will make it possible to directly compare the cash flow to the expected rate of return at later stages of the analysis. 
where:

$\mathrm{E}$ - equity value determined on the basis of an income-based method;

FCFE - free cash flow to equity;

$r_{e}$ - owner-expected rate of return;

$\mathrm{t}$ - number of cash flows.

FCFE is calculated as follows [Liu and Switzer, 2010, pp. 333-346; Jackowicz et al., 2017, pp. 914-927]:

$$
F C F E=P A T+A-W C I-I+D_{N}-D_{R}+R V_{F C F E}
$$

where:

$P A T$ - the profit after tax;

$A$ - the amortization;

$W C I$ - the non-cash working capital investment (expenditures to increase the net working capital);

$I$ - capital investment;

$D_{N}$ the new debt (inflows from contracted loans and borrowings);

$D_{R}$ - debt repayment (expenditures to repay the principal instalments on incurred loans and borrowings);

$R V_{F C F E}$ - the residual value in the last year of analysis.

According to formula (1), to valuate an entity using an income-based approach, it is necessary to estimate its future forecast cash flow and then discount the obtained values according to a given current day.

Equity value (E) may also be determined by a formula for the present value of perpetuity. The formula will look as follows:

$$
E=\frac{F C F E_{s}}{r_{e}}
$$

where:

$\mathrm{FCFE}_{\mathrm{S}}$ - value of annual average standard cash flow.

If we transform the formula for perpetuity (formula 3), we obtain another formula, making it possible to determine the value of the annual average standard cash flow to equity $\left(\mathrm{FCFE}_{\mathrm{S}}\right)$ :

$$
F C F E_{s}=E \cdot r_{e}
$$

(formula 4)

If we, therefore. know the equity value (E) (which can be determined using formula 1), we are able to estimate the value of the annual average standard cash flow to equity $\left(\mathrm{FCFE}_{\mathrm{S}}\right)$. Thus, it is possible to determine the annual average rate of return that can be obtained by owners as a result of employment of their capital (BV). The value of this rate may be determined following a traditional approach applied in calculating the rates of return on investment (e.g., ROI - Return on Investment). In the case of such an approach, rates of return represent 
the relationship between the value of the annual financial gains and the value of the invested capital. This way, the formula making it possible to estimate the attainable rate of return on the pursued business would look as follows:

$$
r_{r}=\frac{F C F E_{s}}{B V}
$$

where:

$\mathrm{r}_{\mathrm{r}}$ - actual rate of return, attainable by enterprise owners;

BV - book value of equity (book value of the capital employed by enterprise owners).

If the value of the obtained annual average cash flow meets the expectations of the enterprise owners, then the expected rate of return $\left(r_{e}\right)$ equals the actual rate of return $\left(r_{r}\right)$. Moreover, it is important to note that familiarity with the abovementioned formula makes it possible to establish the relationship between the equity value (E) and the book value of equity (BV), which ensures that the owner-expected rate of return is attained. If we take the formula for the actual rate of return (formula 5) and substitute $\mathrm{FCFE}_{\mathrm{S}}$ with one element from formula 3 , we obtain the following formula:

$$
r_{r}=\frac{E \cdot r_{e}}{B V}
$$

According to this formula, it appears that in the case of an equity value (E) equal to the book value of equity $(\mathrm{BV})$, the expected rate of return $\left(\mathrm{r}_{\mathrm{e}}\right)$ equals the actual - obtained - rate of return $\left(r_{r}\right)^{3}$. If the equity value $(\mathrm{E})$ exceeds the book value of equity $(\mathrm{BV})$, the rate of return attainable by the owners $\left(r_{r}\right)$ will be higher than the expected rate of return $\left(r_{e}\right)$.

On the basis of the abovementioned considerations, it is possible to formulate a general principle concerning creation of value for enterprise owners in the following way:

1) If the value of an equity valued by means of income-based methods (E) is higher than the book value of the owners' capital (BV), equity providers attain a rate of return that is higher than the expected rate of return $\left(r_{e}\right)$. This relationship may be presented using the following formula:

$$
\mathrm{E}>\mathrm{BV}<=>\mathrm{r}_{\mathrm{r}}>\mathrm{r}_{\mathrm{e}}
$$

2) If the value of an equity valued by means of income-based methods (E) is equal to the book value of the owners' capital (BV), equity providers attain a rate of return that is equal to the expected rate of return $\left(\mathrm{r}_{\mathrm{e}}\right)$. This relationship may be presented using the following formula:

$$
\mathrm{E}=\mathrm{BV} \Leftrightarrow>\mathrm{r}_{\mathrm{r}}=\mathrm{r}_{\mathrm{e}}
$$

\footnotetext{
3 Assuming that $r_{r}=\frac{E \cdot r_{e}}{B V}$ and $\mathrm{E}=\mathrm{BV}$, then $\mathrm{r}_{\mathrm{r}}=\mathrm{r}_{\mathrm{e}}$
} 
3) If the value of an equity valued by means of income-based methods (E) is lower than the book value of the owners' capital (BV), equity providers do not attain an expected rate of return on the employed capital $\left(\mathrm{r}_{\mathrm{e}}\right)$. This relationship may be presented using the following formula:

$$
\mathrm{E}<\mathrm{BV}<=>\mathrm{r}_{\mathrm{r}}<\mathrm{r}_{\mathrm{e}}
$$

The abovementioned regularities stem from the principles of mathematical finance and can be illustrated using the following example.

\section{Example 1}

A company has been valued by means of an income-based method (the values for particular variants have been given in table 1$)$. The value of equity contributed by the owners $(B V)$ is $1,000 \mathrm{MU}$. The rate of return expected by the equity providers $\left(r_{e}\right)$ is $10 \%$.

Table 1. Assumptions for calculations of the annual average cash flow and the actual rate of return attained by owners

\begin{tabular}{|c|c|c|c|}
\hline & Variant I & Variant II & Variant III \\
\hline Book value of equity $(\mathrm{BV})$ & 1,000 & 1,000 & 1,000 \\
\hline Equity value determined by means of an income-based method $(E)$ & 1,500 & 1,000 & 500 \\
\hline Owner-expected rate of return $\left(r_{e}\right)$ & $10 \%$ & $10 \%$ & $10 \%$ \\
\hline Annual average value of free cash flow to equity $\left(\mathrm{FCFE}_{\mathrm{S}}\right)-($ formula 4$)$ & 150 & 100 & 50 \\
\hline Actual rate of return attained by owners $\left(r_{r}\right)-($ formula 5$)$ & $15 \%$ & $10 \%$ & $5 \%$ \\
\hline
\end{tabular}

Source: Own work.

The value of the annual average standard free cash flow to equity $\left(\mathrm{FCFE}_{\mathrm{S}}\right)$ has been determined for each of the variants. To this end, the aforesaid formula 4 was applied. The following results were obtained for particular variants: $150 \mathrm{MU}$ (the product of an equity value established by means of income-based methods $(E)$ and the expected rate of return $-r_{e}(10 \%)$ ), $100 \mathrm{MU}, 50 \mathrm{MU}$. Moreover, the actual rate of return on capital contributed by the owners $\left(\mathrm{r}_{\mathrm{r}}\right)$ was determined for each of the variants by dividing the annual average value of the cash flow $\left(\mathrm{FCFE}_{\mathrm{S}}\right)$ by the book value of equity $(\mathrm{BV})$ - by way of application of the aforementioned formula 5 (the following results were obtained: $15 \%, 10 \%$, and $5 \%$, respectively). The obtained results let us formulate the following conclusions:

1) For variant $\mathrm{I}$ - the equity value estimated by means of an income-based method $(\mathrm{E}=1,500 \mathrm{MU})$ is higher than the value of the employed equity ( $\mathrm{BV}=1,000 \mathrm{MU})$. Moreover, the actual attained rate of return on the capital employed by enterprise owners (15\%) is higher than the expected rate of return applied to discount the free cash flow (10\%).

2) For variant II - the equity value estimated by means of an income-based method $(\mathrm{E}=1,000$ $\mathrm{MU})$ is equal to the value of the employed equity ( $\mathrm{BV}=1,000 \mathrm{MU})$. Moreover, the actual 
attained rate of return on the capital employed by enterprise owners (10\%) is equal to the expected rate of return applied to discount the free cash flow (10\%).

3) For variant III - the equity value estimated by means of an income-based method ( $E=500$ $\mathrm{MU})$ is lower than the value of the employed equity (BV=1,000 MU). Moreover, the actual attained rate of return on the capital employed by enterprise owners (5\%) is lower than the expected rate of return applied to discount the free cash flow (10\%).

The example shown above proves the aforesaid relationship between an equity value obtained by means of an income-based method (E) and the book value of equity (BV) to be valid. According to the earlier argument, if the result of a valuation performed by means of income-based methods (E) is lower than the book value of the owners' capital (BV), the equity providers do not attain an expected rate of return on the employed capital. Thus, the question is: should an enterprise that does not meet the financial expectations of its owners $(\mathrm{E}<\mathrm{BV})$ continue its business activity? The answer to this question is not simple and requires further analyses to be performed.

First, it is necessary to consider a possibility of introducing restructuring measures that would make the rate of return required by the owners attainable (i.e., $r_{r} \geq r_{e}$ and $E \geq B V$ ). Restructuring may focus on increasing the value of the enterprise's income or on decreasing the value of the employment of equity. It is possible to increase the value of income by, e.g., increasing revenues, cost optimization, changes in the scope of working capital management, and optimization of investment expenditures. Decreasing the value of equity employment, in turn, is related to a broadly understood restructuring of financing of the activity of a given enterprise. If the abovementioned measures do not make it possible for the income value of the equity (E) to exceed the value of the employed equity (BV), it is necessary to conduct additional analyses to verify the financial rationality of the continuation of the enterprise's business activity.

At such stage of analysis, it is reasonable to consider the option of liquidation. However, it will be first necessary to estimate the liquidation value of equity (LBV). Thus far, we have been using the term of book value of employed equity (BV) - the capital that has been actually contributed by the enterprise owners and gained from the enterprise's profits. Now, we need to focus on the actual value equity providers would obtain if they decided to opt for liquidation. The liquidation value of equity (LBV) is the liquidation value of a firm's assets reduced by the value of liabilities and by costs of the firm's liquidation - if any such costs should apply in a given case. In other words, equity liquidation value (LBV) represents the value that the enterprise owners could obtain in the event of liquidation of their enterprise. Usually this value is not equal to the book value of equity (BV), which reflects the value of the capital employed by the enterprise owners. For the needs of analysis of reasonability of company liquidation, it is necessary to treat employed capital according to the principle of "spilt milk", which is applied in the assessment of profitability of investment projects [Pike and Neale 2003, pp. 114-117; Mielcarz, 2013, pp. 55-59]. According to this principle, any sunk 
$\operatorname{costs}^{4}$ should not be considered when assessing the profitability of investment projects. The book value of equity (BV) should be treated in a similar way when assessing the rationality of company liquidation. The value of the capital employed by the firm's owners is not important; what matters is its real market value in the circumstances of liquidation of the firm.

As part of further analysis of the rationality of voluntary liquidation, it is necessary to make a comparison of the equity value determined on the basis of an income-based method (E) and the liquidation value of equity (LBV). If the equity value (E) exceeds the liquidation value of equity (LBV), it should be acknowledged that - according to mathematical financial principles - company owners attain the expected rate of return on the liquidation (real) value of equity $\left(r_{r}{ }^{35}\right)$. Therefore, company liquidation in such conditions is not justified in financial terms. A problem appears if the abovementioned relationship does not apply - then equity providers do not attain the expected rate of return even if this rate is calculated on the basis of liquidation value of equity. In such a case, it will be reasonable to continue a given firm's business activity only if the firm's owners accept a lower rate of return on equity than what they expected. If it turns out, however, that the business does not produce a rate of return $\left(r_{r}{ }^{\prime}\right)$ equal to the risk-free rate of return $\left(\mathrm{r}_{\mathrm{f}}\right)$ (e.g., a rate attainable through investments in risk-free securities), then a further pursuit of business activity is not rational in financial terms and not profitable. In such a case, the equity providers will gain larger profits if they decide to liquidate the enterprise and invest the obtained capital in risk-free assets. The abovementioned relations concerning firm liquidation may be expressed in the following way:

1) If the value of equity determined on the basis of an income-based method (E) is higher than the liquidation value of equity (LBV), then the rate of return on the liquidation value of equity attained by equity providers $\left(\mathrm{r}_{\mathrm{r}}{ }^{\prime}\right)$ is larger than the expected rate of return on the capital employed $\left(r_{\mathrm{e}}\right)$. This relationship may be presented using the following formula:

$$
\mathrm{E}>\mathrm{LBV}<=>\mathrm{r}_{\mathrm{r}}{ }^{\prime}>\mathrm{r}_{\mathrm{e}}
$$

where:

$\mathrm{r}_{\mathrm{r}}{ }^{\prime}$ - actual rate of return, attainable by the owners assuming that it is calculated on the basis of the liquidation value of equity.

In this case, enterprise liquidation is not justified in financial terms because enterprise owners attain a rate of return that is higher than the expected rate of return on the liquidation value of equity.

2) If the value of equity determined on the basis of an income-based method (E) is equal to the liquidation value of equity (LBV), then the rate of return on the liquidation value of equity attained by equity providers $\left(\mathrm{r}_{\mathrm{r}}{ }^{\prime}\right)$ is equal to the expected rate of return on the capital employed $\left(r_{\mathrm{e}}\right)$. This relationship may be presented using the following formula:

4 Expenses incurred before the moment of initiation of the analysis of investment profitability, which do not present any market value or may not be sold on the day when the analysis is performed.

5 In this case, the rate of return should be determined applying the following formula: $r_{r}{ }^{\prime}=\frac{F C F E_{s}}{L B V}$ 


$$
\mathrm{E}=\mathrm{LBV}<=\mathrm{r}_{\mathrm{r}}{ }^{\prime}=\mathrm{r}_{\mathrm{e}}
$$

In this case, enterprise liquidation is not justified in financial terms as well because enterprise owners attain the expected rate of return on the liquidation value of equity.

3) If the value of equity determined on the basis of an income-based method (E) is lower than the liquidation value of equity (LBV), then the rate of return on the liquidation value of equity attained by equity providers $\left(r_{r}{ }^{\prime}\right)$ is lower than the expected rate of return on the capital employed $\left(r_{\mathrm{e}}\right)$. This relationship may be presented using the following formula:

$$
\mathrm{E}<\mathrm{LBV} \Leftrightarrow>\mathrm{r}_{\mathrm{r}}{ }^{\prime}<\mathrm{r}_{\mathrm{e}}
$$

In this case, assessment of the rationality of enterprise liquidation should be subject to further analysis. It is particularly important to determine the risk-free rate $\left(r_{f}\right)$. It will determine further decisions concerning enterprise liquidation in the following way:

3.1. If the rate of return on the liquidation value of equity $\left(r_{r}{ }^{\prime}\right)$ is larger than the riskfree rate $\left(r_{f}\right)$, i.e., $r_{r}{ }^{\prime}>r_{f}$, the decision for enterprise liquidation is not obvious and will depend on several factors. First, because enterprise owners do not attain the expected rate of return, they need to determine alone what minimum rate of return in certain business conditions is acceptable to them. Surely, the closer the attained rate of return $\left(r_{r}{ }^{\prime}\right)$ is to the risk-free rate $\left(r_{f}\right)$, the more enterprise owners will be willing to decide to liquidate their enterprise. Moreover, if enterprise owners see an opportunity to utilize the liquidation value of equity in a more effective (profitable) way, their inclination toward liquidation of their enterprise and utilizing the capital in possession in an alternative way will grow.

It is important to stress that if enterprise owners decided to liquidate their enterprise in the situation subject to discussion $\left(r_{r}>r_{f}\right)$ and use the obtained capital to invest it in risk-free assets, they would attain a lower annual average standard cash flow than the cash flow they could gain from investing the capital in the enterprise.

3.2. If the rate of return on liquidation value of equity $\left(r_{r}{ }^{\prime}\right)$ is equal to the risk-free rate $\left(r_{f}\right)$, i.e., $r_{r}{ }^{\prime}=r_{f}$, regardless of whether enterprise owners decide to continue their business activity or to liquidate the enterprise and invest the resources obtained this way in risk-free securities, according to mathematical finance principles, they will attain the same annual average standard cash flow. Considering that conducting business activities involves a higher risk than investing in risk-free securities, from a financial perspective it seems rational to decide to liquidate the enterprise.

3.3. If the rate of return on liquidation value of equity $\left(r_{r}{ }^{\prime}\right)$ is lower than the risk-free rate $\left(r_{f}\right)$, i.e., $r_{r}{ }^{\prime}<r_{f}$, then if enterprise owners decided to liquidate their enterprise and use the obtained capital to invest it in risk-free assets, they would attain a higher annual average standard cash flow than the cash flow they could gain from investing the capital in the enterprise. In this situation, looking at the issue from a financial 
perspective, the continuation of business activity is unprofitable - the enterprise should be liquidated.

To summarize, if we consider the financial aspects, it appears that an enterprise should be put into liquidation if the following circumstances occur:

$$
r_{r}^{\prime} \leq r_{f}
$$

which can also be expressed in the following way:

$$
r_{f} \geq \frac{F C F E_{s}}{L B V}
$$

The regularities presented in items 3.1, 3.2, and 3.3 have been illustrated with the following example.

\section{Example 2}

A company has been valued by means of an income-based method (the values for particular variants have been given in table 1). The value of equity contributed by the enterprise owners $(B V)$ is 1,000 MU, and their liquidation value amounts to $500 \mathrm{MU}$. The rate of return expected by the equity providers $\left(r_{e}\right)$ is $10 \%$. At the same time, we know that the risk-free rate is $2 \%$.

Table 2. Assumptions for calculations of the annual average cash flow and the actual rate of

\begin{tabular}{|c|c|c|c|}
\hline & Variant I & Variant II & Variant III \\
\hline Book value of equity $(B V)$ & 1,000 & 1,000 & 1,000 \\
\hline Liquidation value of equity (LBV) & 500 & 500 & 500 \\
\hline Equity value determined by means of an income-based method $(E)$ & 400 & 100 & 50 \\
\hline Owner-expected rate of return $\left(r_{e}\right)$ & $10 \%$ & $10 \%$ & $10 \%$ \\
\hline Annual average value of free cash flow to equity $\left(F C F E_{S}\right)-($ formula 4$)$ & 40 & 10 & 5 \\
\hline $\begin{array}{l}\text { Actual rate of return attained by enterprise owners, calculated on the } \\
\text { basis of liquidation value of equity }\left(r_{r}^{\prime}\right)-\left(F C F E_{S} / L B V\right)\end{array}$ & $8 \%$ & $2 \%$ & $1 \%$ \\
\hline
\end{tabular}
return attained by owners

Source: Own work.

Table 3. Analysis of the profitability of investment in free-risk assets

\begin{tabular}{|l|c|c|c|}
\cline { 2 - 4 } \multicolumn{1}{c|}{} & Variant I & Variant II & Variant III \\
\hline Risk-free rate $\left(r_{f}\right)$ & $2 \%$ & $2 \%$ & $2 \%$ \\
\hline Liquidation value of equity $(L B V)$ & 500 & 500 & 500 \\
\hline Investment cash flow $(C F)-\left(r_{f} *\right.$ LBV) & 10 & 10 & 10 \\
\hline
\end{tabular}

Source: Own work. 
In each of the analyzed cases, the liquidation value of equity (LBV) is higher than the equity value determined on the basis of an income-based method (E), which means that the enterprise owners do not attain the expected rate of return in any of these cases. The point of the example is to present circumstances where conducting business activities gives less profit than investing in risk-free assets.

As in the case of the aforementioned example 1, the value of annual average free cash flow to equity $\left(\mathrm{FCFE}_{\mathrm{S}}\right)$ has been determined for each variant. To this end, formula 4 was applied. The following results were obtained for particular variants: $40 \mathrm{MU}, 10 \mathrm{MU}$, and $5 \mathrm{MU}$, respectively. Moreover, the rate of return on liquidation value of equity $\left(r_{r}{ }^{\prime}\right)$ was determined for each of the variants by dividing the annual average value of cash flow $\left(\mathrm{FCFE}_{\mathrm{S}}\right)$ by the liquidation value of equity (LBV), with the following results obtained for the said variants: $8 \%, 2 \%$, and $1 \%$, respectively. The last step was to calculate the value of cash flow (CF) attainable from the capital resulting from firm liquidation, which would be invested in risk-free assets. The same results were obtained for each variant: $10 \mathrm{MU}$ (product of the value of the invested capital (LBV), i.e., $500 \mathrm{MU}$ and of the risk-free rate $\left.\left(\mathrm{r}_{\mathrm{f}}\right) 2 \%\right)$.

The obtained results let us formulate the following conclusions:

1) For variant $I$ - the rate of return attained by the owners $\left(r_{r}{ }^{\prime}\right)$ is higher than the risk-free rate $\left(r_{f}\right)$ - therefore, the annual value of standard free cash flow to equity $\left(\mathrm{FCFE}_{\mathrm{S}}\right)$ gained from the conducted business activities - $40 \mathrm{MU}$ - is higher than the cash flow attainable by investing the liquidation value of equity (LBV) in risk-free assets - $10 \mathrm{MU}$.

2) For variant II - the rate of return attained by the owners $\left(r_{r}{ }^{\prime}\right)$ is equal to the risk-free rate $\left(r_{f}\right)$ - therefore, the annual value of standard free cash flow to equity $\left(\mathrm{FCFE}_{\mathrm{S}}\right)$ gained from the conducted business activities - $10 \mathrm{MU}$ - is equal to the cash flow attainable by investing the liquidation value of equity (LBV) in risk-free assets - $10 \mathrm{MU}$.

3) For variant III - the rate of return attained by the owners $\left(r_{r}{ }^{\prime}\right)$ is lower than the risk-free rate $\left(r_{f}\right)$ - therefore, the annual value of standard free cash flow to equity $\left(\mathrm{FCFE}_{\mathrm{S}}\right)$ gained from the conducted business activities - $5 \mathrm{MU}$ - is lower than the cash flow attainable by investing the liquidation value of equity (LBV) in risk-free assets - $10 \mathrm{MU}$.

The example proves the validity of the aforesaid argument stating that if the rate of return on the conducted business activity is lower than or equal to the rate of return attainable by investing the liquidation value of equity in risk-free assets $\left(r_{r}{ }^{\prime} \leq r_{f}\right)$, then it is financially unprofitable to continue the said business activity. At the same time, if such a situation appears, it means that the annual average standard cash flow gained from risk-free assets obtained from the liquidation capital (CF) is higher than or equal to the annual average standard cash flow gained from the conducted business activity $\left(\mathrm{FCFE}_{\mathrm{S}}\right)$.

The discussion on financial rationality of enterprise liquidation has been summarized and presented in schema 1. 
Schema 1. Assessment of rationality of voluntary liquidation of an enterprise

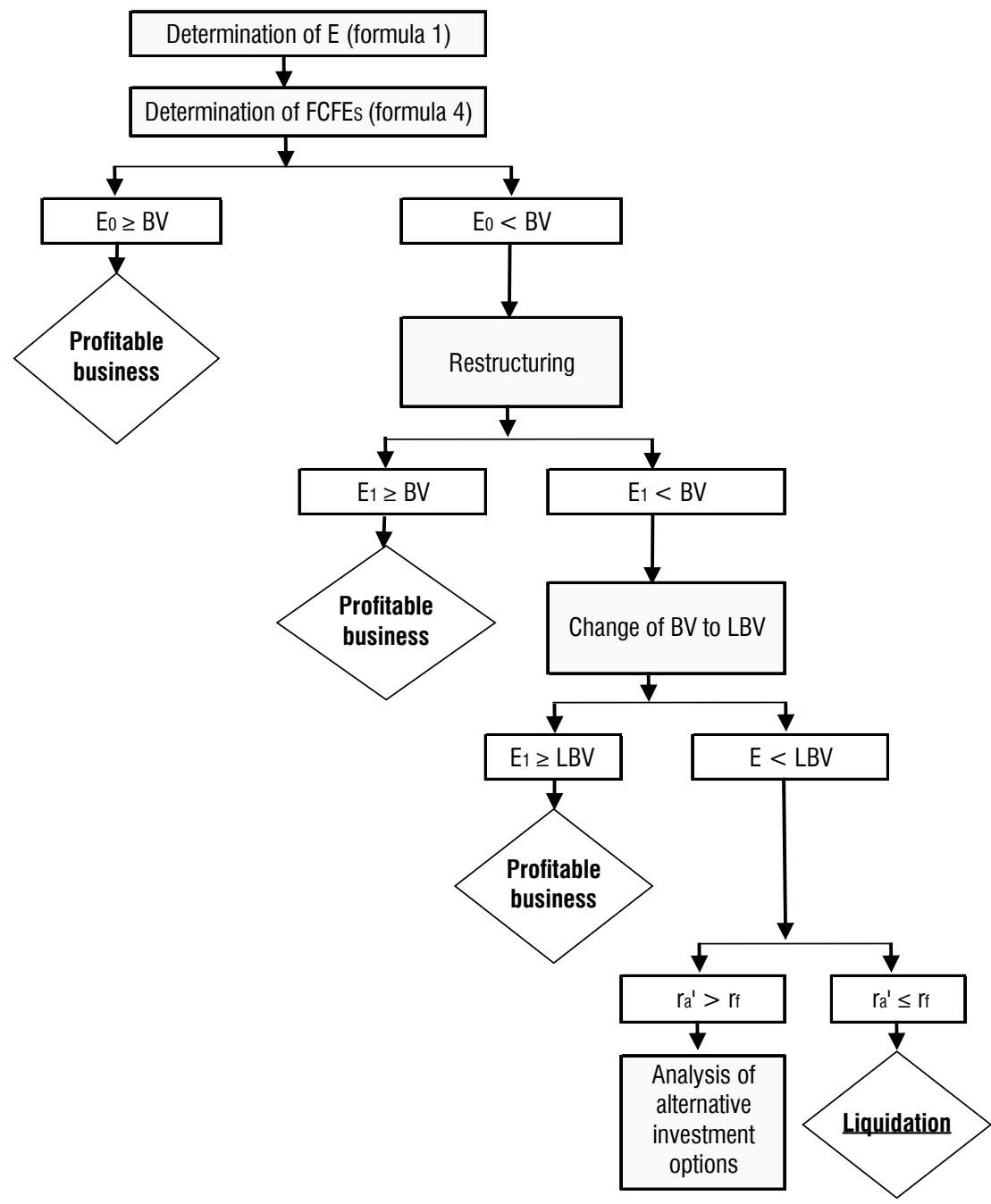

Legend:

$\mathrm{E}_{0}$ - equity value before restructuring;

$\mathrm{E}_{1}$ - equity value after restructuring.

Source: Own work.

\section{Constraints and conditions of application of the presented model}

When applying the discussed model of reasonability of company liquidation, it is necessary to remember about determining the value standard which will define the parties for whom the abovementioned analysis is carried out. Selection of the value standard will determine, among others, the expected rates of return, and will thus affect the conducted analysis. Moreover, the 
value standard may have an impact on the cash flows estimated as part of the model, whose value will be crucial to the decision on voluntary company liquidation.

Also, it should be stressed that the presented approach takes into consideration only the financial aspects of such a decision. The presented analysis does not take into account the extra-financial benefits and expectations related to operating a business. Meanwhile, the source literature points to a range of benefits of extra-financial nature, of being an entrepreneur. According to most of these studies, entrepreneurs speak of a greater level of job satisfaction in comparison to standard employees [e.g., Blanchflower and Oswald, 1998, pp. 26-60; Bianchi, 2012, pp. 273-286]. The self-employed tend to be more optimistic and satisfied, which translates into a higher level of their happiness [Blanchflower and Oswald, 1998, pp. 26-60]. Entrepreneurial satisfaction comes also from the sense of professional independence, which includes autonomy and flexibility in shaping and creating jobs. Another factor is also job self-efficacy [Phama et al., 2018]. Furthermore, the level of work-related stress appears to be lower among the self-employed [Hessels et al., 2017, pp. 178-196], which explains lower levels of depression and greater levels of overall satisfaction [Bradley and Roberts, 2004, pp. 37-58].

Another problem in the light of the presented approach is the application of an appropriately matched discount rate. As argued in the source literature, the main problem with liquidation valuation is related exactly to the discount factor. Both practitioners and theorists share the opinion that CAPM is not the right method for liquidation valuation. Unfortunately, no good alternative has been offered yet [Poborský, 2015, pp. 386-393]. Besides, the owner-expected rate of return (re) employed in the discussed approach should be determined on the basis of one of the already known models - e.g.: CAPM [Lintner, 1965, pp. 13-37; Sharpe, 1964, pp. 425-442]. The CAPM model has met with considerable criticism, with Fama and French [1992] being behind the majority of it. A significant amount of literature from over several decades has concentrated on the estimation aspect of CAPM, on systematic risk or beta, to be more precise. One of the first aspects of criticism addresses the instability of its estimates over time. Researchers such as Blume [1971, 1975] and Ferson and Harvey [1991] have argued that the estimated betas are statistically significant time variation. Given that, these last three works speak in favour of substituting the static CAPM with some forms of time-varying beta. However, as proven by Ghysels [1998], if the dynamics of the beta is defined incorrectly, there is a risk of occurrence of pricing errors that may be potentially greater than when a constant beta is adopted. Another problem with the CAPM model is about determining the beta coefficient in the event the market price of the analysed capital is not available [Michalak, 2012, pp. 583-593]. In such circumstances, a possible solution is to determine the said beta coefficient on the basis of the data of similar firms which are publicly listed. Still, in many cases it is extremely difficult to find companies that operate within the same industry and are very similar to each other even in terms of size [Ingram and Margetis, 2010, pp. 160-167]. Another problem related to beta calculation is the direct transposition of past data into the future. It is important to bear in mind that the cost of capital refers to the future. It is the rate of return which the investors expect to achieve [Michalak, 2014, pp. 27-37]. 
To summarize, when applying the approach discussed above, it is important to remember about the conditions in which the analysis is carried out. They are of crucial importance to the performed analysis. What is more, it is good to bear in mind that the results of the analysis involve certain simplifications and limitations, and so the final decision on firm liquidation may not be made only on the basis of the findings presented in the model in question.

\section{Summary}

The contemporary literature devoted to the subject matter of company liquidation focuses mainly on determinants of company liquidation and on the qualities of liquidated firms. It is also common to present models designed to forecast bankruptcy. Meanwhile, not much has been written about models developed to assess the rationality of voluntary liquidation of an enterprise in specific circumstances. Considering that the issue is of great significance to enterprise owners, whose goal is to optimize the utilization of the invested capital, the author of the study has decided to introduce a concept making it possible to assess the reasonability of decisions for voluntary liquidation of enterprises.

The presented idea acts as an organized and systematized approach to the assessment of financial rationality of the voluntary liquidation of firms. By way of applying fundamental principles of mathematical finance and the concept of VBM, the author of the paper has offered a decision-making path that should precede decisions of liquidation of business entities. One of the advantages of the presented solution is its easy applicability in economic practice. Application of the described procedures makes it possible to assess the financial rationality of conducting a given business activity. Because the existing literature devoted to the subject does not cover the issue in much detail, the proposed concept constitutes an important supplement - and one of significance from a practical point of view.

A model developed by Y. Chen et al. [1995] may be a certain alternative to the said solution. If we compare both concepts, we arrive at the following differences:

1. The concept of Y. Chen et al. [1995] focuses on the assessment of new investments whose pursuit may let a given enterprise survive on the market. It is based on the NPV method. The model discussed in this study lets one assess the financial rationality of conducting business activity on the basis of income gained by the company owners with respect to the capital they employ (it is based on a comparative analysis of the attained and expected rates of return on the capital invested in the firm). The applied methodology is based on the concept of VBM (Value Based Management) - and this is why the concept presented in this study seems to be more versatile (i.e., it does not focus on a single investment, but instead on the entire investment portfolio that may grant capital providers certain profits.

2. Y. Chen et al. [1995] developed a tool that may be applied in the circumstances when a firm is in a difficult financial situation. The model presented in this study, in turn, makes it 
possible to look for solutions already when the first symptoms of financial trouble appear

- meaning when the pursued business activity does not grant the enterprise owners the expected rate of return.

3. The model proposed by Y. Chen et al. [1995] is based on two scenarios, namely pessimistic and optimistic, with a 50\% probability of occurrence of either of them. The concept discussed by the author of this paper is not based on any probability calculus, as there is one most likely scenario considered at each stage of analysis.

Considering the differences between the two concepts covered above, it appears that the two approaches are not exactly interchangeable alternatives.

At the same time, it is necessary to stress that the solutions presented in this study are not fully flawless, either. Above all, the presented concept is based on income valuation of an enterprise, which is known to result from adopted assumptions, among others. Wrong assumptions may thus distort the results of analysis. Moreover, assumptions may be modified because of the occurrence of many various events (e.g., economic changes), which may lead to changes in the results of calculations performed using the presented model. It is therefore important to bear in mind that even if the model shows that it is reasonable to liquidate a given firm, any changes in the circumstances (and, in effect, in the made assumptions) may change the results of analysis to a great extent. In other words, it is important to note that a continuation of business activity even in a difficult situation leaves some future options (e.g., in the event of economic changes) - unlike liquidation, which will make it impossible to take advantage of such options if the conditions in which a given business is operated change. Still, it seems that the presented solution may become a useful tool in assessing the financial rationality of the voluntary liquidation of enterprises.

Further developments related to the solution presented herein should, therefore, focus on an empirical analysis of the effectiveness of the discussed approach. Empirical analyses of the expected rates of return, of transaction costs, and of cash flows of firms being in a difficult financial situation should provide insights that would make it possible to perform a reliable calculation of liquidation value and, therefore, offer information required to make a decision on a voluntary enterprise liquidation.

\section{References}

1. Altman E.I., 1968. Financial ratios, discriminant analysis and the prediction of corporate bankruptcy. Journal of Finance, Vol. 23, No. 4, pp. 589-609.

2. Altman E.I., 1984. A further empirical investigation of the bankruptcy cost question. Journal of Finance, Vol. 39, No. 4, pp. 1067-1089.

3. Altman E.I., 1993. Corporate Financial Distress and Bankruptcy. New York: John Wiley \& Sons.

4. Amendola A., Restaino M., Sensini L., 2015. An analysis of the determinants of financial distress in Italy: A competing risks approach. International Review of Economics and Finance, Vol. 37, pp. 33-41. 
5. Balcaen S., Manigart S., Ooghe H., 2011. From distress to exit: determinants of the time to exit. Journal of Evolutionary Economics, Vol. 21, No. 3, pp. 407-446.

6. Balcaen S., Manigart S., Buyze J., Ooghe H., 2012. Firm exit after distress: differentiating between bankruptcy, voluntary liquidation and M\&A. Small Business Economics, Vol. 39, No. 4, pp. 949-975.

7. Bandopadhyaya A., 1994. An estimation of the hazard rate of firms under Chapter 11 protection. The Review of Economics and Statistics, Vol. 76, No. 2, pp. 346-350.

8. Berkovitch E., Kim EH., 1990. Financial Contracting and Leverage Induced Over- and UnderInvestment Incentives, Journal of Finance, Vol. 45, No. 3, pp. 765-794.

9. Bianchi M., 2012. Financial development, entrepreneurship, and job satisfaction. Review of Economics and Statistics, Vol. 94, No. 1, pp. 273-286.

10. Blanchflower DG., Oswald A.J., 1998. What makes an entrepreneur? Journal of Labor Economics, Vol. 16, No. 1, pp. 26-60.

11. Blume M.E., 1971. On the assessment of risk. The Journal of Finance, Vol. 26, No. 1, pp. 1-10.

12. Blume M.E., 1975. Beta and the regression tendencies. The Journal of Finance, Vol. 30, No. 1, pp. 785-795.

13. Bradley D.E., Roberts J.A., 2004. Self-employment and job satisfaction: investigating the role of self-efficacy, depression, and seniority. Journal of Small Business Management, Vol. 42, No. 1, pp. 37-58.

14. Burgstahler D.C., Dichev ID., 1997. Earnings, Adaptation and Equity Value. The Accounting Review, Vol. 72, No. 2, pp. 187-215.

15. Chen Y., Weston J.F., Altman E.I., 1995. Financial Distress and Restructuring Models. Financial Management, Vol. 24, No. 2, pp. 57-75.

16. Copeland T., Koller T., Murrin J., 1990. Valuation: Measuring and Managing the Value of Companies. New York: John Wiley \& Sons.

17. Couwenberg O., de Jong A., 2008. Costs and recovery rates in the Dutch liquidation-based bankruptcy system. European Journal of Law and Economics, Vol. 26, No. 2, pp. 105-127.

18. Damodaran A., 2006. Damodaran on Valuation: Security Analysis for Investment and Corporate Finance. Hoboken: John Wiley \& Sons.

19. Delaney K.J., 1991. Strategic Bankruptcy: How Corporations and Creditors Use Chapter 11 to their Advantage. Berkeley: University of California Press.

20. Denis D.K., Rodgers K.J., 2007. Chapter 11: duration, outcome, and post-reorganization performance. Journal of Financial and Quantitative Analysis, Vol. 42, No. 1, pp. 101-118.

21. Erwin G.R., McConnell J.J., 1997. To live or let die? An empirical analysis of piecemeal voluntary corporate liquidations. Journal of Corporate Finance, Vol. 3, No. 4, pp. 325-354.

22. Fama E.F., French K.R., 1992. The cross-section of expected stock returns. The Journal of Finance, Vol. 47, No. 2, pp. 427-465.

23. Fan H., Sundaresan S.M., 2000. Debt valuation, strategic debt service, and optimal dividend policy. Review of Financial Studies, Vol. 13, No. 4, pp. 1057-1099.

24. Fernández P., 2007. Valuing companies by cash flow discounting: ten methods and nine theories. Managerial Finance, Vol. 33, No. 11, pp. 853-876. 
25. Ferson W.E., Harvey C.R., 1991. The variation of economic risk premiums. Journal of Political Economy, Vol. 99, No. 2, pp. 385-415.

26. Francois P., Morellec E., 2004. Capital structure and asset prices: Some effects of bankruptcy procedures. Journal of Business, Vol. 77, No. 2, pp. 387-411.

27. Galai D., Raviv A., Wiener Z., 2017. Liquidation triggers and the valuation of equity and debt. Journal of Banking \& Finance, Vol. 31, No. 12, pp. 3604-3620.

28. Ghosh C., Owers J.E., Rogers R.C., 1991. The financial characteristics associated with voluntary liquidations. Journal of Business Finance and Accounting, Vol. 18, No. 6, pp. 773-789.

29. Ghysels E., 1998. On stable factor structures in the pricing of risk: do time-varying betas help or hurt? The Journal of Finance, Vol. 53, No. 2, pp. 549-573.

30. Harhoff D., Stahl K., Woywode M., 1998. Legal form, growth and exit of West German firms: empirical results for manufacturing, construction, trade and service industries. The Journal of Industrial Economics, Vol. 46, No. 4, pp. 453-488.

31. Hessels J., Rietveld C.A., der Zwan V.P., 2017. Self-employment and work-related stress: the mediating role of job control and job demand. Journal of Business Venturing, Vol. 32, No. 2, pp. 178-196.

32. Higgins R.C., 1995. Analysis for Financial Management. Chicago: Irwin.

33. Hite GL., Owers J.E., Rogers R.C., 1987. The market for interfirm asset sales: Partial sell-offs and total liquidations. Journal of Financial Economics, Vol. 18, No. 2, pp. 229-252.

34. Hunsaker J., 1999. The Role of Debt and Bankruptcy Statutes in Facilitating Tacit Collusion. Managerial and Decision Economics, Vol. 20, No. 1, pp. 9-24.

35. Ingram M., Margetis S., 2010. A practical method to estimate the cost of equity capital for a firm using cluster analysis, Managerial Finance, Vol. 36, No. 2, pp. 160-167.

36. Jackowicz K., Mielcarz P., Wnuczak P., 2017. Fair value, equity cash flow and project finance valuation: ambiguities and a solution. Managerial Finance, Vol. 43, No. 8, pp. 914-927.

37. Jaki A., 2012. Kategoria wartości w niemieckich i anglosaskich standardach wyceny. Zeszyty Naukowe Uniwersytetu Szczecińskiego, Finanse, Rynki Finansowe, Ubezpieczenia, Vol. 51, pp. 553-560.

38. Jensen M.C., Meckling WH., 1976. Theory of the firm: Managerial behavior, agency costs and ownership structure, Journal of Financial Economics, Vol. 3, No. 4, pp. 305-360.

39. John K., 1993. Managing Financial Distress and Valuing Distressed Securities: A Survey and a Research Agenda, Financial Management, Vol. 22, no. 3, pp. 60-78.

40. Jones F.L., 1987. Current techniques in bankruptcy prediction. Journal of Accounting Literature, Vol. 6, pp. 131-164.

41. Jones S., Hensher D.A., 2007. Modelling corporate failure: A multinomial nested logit analysis for unordered outcomes. The British Accounting Review, Vol. 39, No. 1, pp. 89-107.

42. Kanatas, G. and Jianping Qi, 2004. Imperfect competition, debt, and exit. Financial Management, Vol. 33, No. 2, pp. 29-49.

43. Kim H.E., Schatzberg J.D., 1987. Voluntary corporate liquidations. Journal of Financial Economics, Vol. 19, No. 2, pp. 311-328.

44. Li K., 1999. Bayesian analysis of duration models: an application to Chapter 11 bankruptcy. Economics Letters, Vol. 63, No. 3, pp. 305-312. 
45. Lintner J., 1965. The valuation of risk assets and the selection of risky investments in stock portfolios and capital budgets. The Review of Economics and Statistics, Vol. 47, No. 1, pp. 13-37.

46. Liu J., Switzer L., 2010. Liquidity Risk, Firm Risk, and Issue Risk Premium Effects on the Abnormal Returns to New Issues of Convertible Bonds. International Journal of Business, Vol. 15, No. 3, pp.333-346.

47. Mandl G., Rabel K., 1997. Unternehmensbewertung. Wien, Frankfurt: Ueberreuter.

48. Matschke MJ., Brősel G., 2011. Wycena przedsiębiorstwa, funkcje, metody, zasady. Warszawa: Wolters Kluwer Polska.

49. Matschke MJ., Brősel G., Matschke X., 2010. Fundamentals of Functional Business Valuation. Journal of Business Valuation and Economic Loss Analysis, Vol. 5, No. 1, pp. 1-39.

50. Michalak A., 2012. Ograniczenia modelu CAPM i alternatywne propozycje w zakresie wyceny kosztu kapitału własnego przedsiębiorstw górniczych, Zeszyty Naukowe Uniwersytetu Szczecińskiego, Finanse, Rynki Finansowe, Ubezpieczenia, Vol. 51, pp. 583-593.

51. Michalak A., 2014. Klasyczne a innowacyjne metody szacowania kosztu kapitału własnego przedsiębiorstwa. Studia Ekonomiczne, Vol. 186, No. 2, pp. 27-37.

52. Mielcarz P., Paszczyk P., 2013. Analiza projektów inwestycyjnych w procesie tworzenia wartości przedsiębiorstwa. Warszawa: PWN.

53. Mielcarz P., Wnuczak P., 2011. DCF Fair Value Valuation, Excessive Assets and Hidden Inefficiencies, Contemporary Economics, Vol. 5, No. 4, pp. 44-57.

54. Mierzejewska W., 2014. Holdings' Level of Complexity During the Crisis. Journal of Management and Financial Sciences, Vol. 7, No. 18, pp. 35-48.

55. Myers S.C., 1974. Interactions of Corporate Financing and Investment Decisions - Implications for Capital Budgeting. Journal of Finance, Vol. 29, No. 1, pp. 1-25.

56. Myers S.C., 1977. Determinants of Corporate Borrowing. Journal of Financial Economics, Vol. 5, No. 2, pp. 147-175.

57. Nel W.S., 2009. Methods of choice in the valuation of ordinary shareholders equity: evidence from theory and practice. Meditari Accountancy Research, Vol. 17, No. 2, pp. 117-135.

58. Orbe J., Ferreira E, Núñez-Antón V., 2001. Modelling the duration of firms in Chapter 11 bankruptcy using a flexible model. Economics Letters, Vol. 71, No. 1, pp. 35-42.

59. Pastena V., Ruland W., 1986. The merger/bankruptcy alternative. The Accounting Review, Vol. 61, No. 2, pp. 288-301.

60. Peel M.J., Wilson N., 1989. The liquidation/merger alternative: some results for the UK corporate sector. Managerial and Decision Economics, Vol. 10, No. 3, pp. 209-220.

61. Phama T., Talaverab O., Zhang M., 2018. Self-employment, financial development, and wellbeing: Evidence from China, Russia, and Ukraine. Journal of Comparative Economics, in press.

62. Pike R., Neale B., 2003. Corporate Finance and Investment: Decisions and Strategies. London: Prentice Hall.

63. Plenborg T., 2002. Firm valuation: comparing the residual income and discounted cash flow approaches. Scandinavian Journal of Management, Vol. 18, No. 3, pp. 303-318.

64. Poborský F., 2015. Fundamentals of the Liquidation Method of Business Valuation. Procedia Economics and Finance, Vol. 25, pp. 386-393. 
65. Poletti-Hughesa J., Ozkanb A., 2014. Ultimate Controllers, Ownership and the Probability of Insolvency in Financially Distressed Firms. Managerial and Decision Economics, Vol. 35, No. 1, pp. 36-50.

66. Pratt S.P., 1989. Defining Standards of Value. Valuation, Vol. 34, No. 2, pp. 4-12.

67. Rappaport A., 1986. Creating Shareholders Value: a guide for Managers and Investors. New York Simon\&Schuster, Inc.

68. Romanowska M., 2014. Strategic Responses to the Crisis. Journal of Management and Financial Sciences, Vol. 7, No. 18, pp. 13-23.

69. Schary M., 1991. The probability of exit. RAND Journal of Economics, Vol. 22, No. 3, pp. 339-353.

70. Scott J., 1981. The probability of bankruptcy: a comparison of empirical predictions and theoretical models. Journal of Banking and Finance, Vol. 5, No. 3, pp. 317-344.

71. Sharpe W., 1964. Capital asset prices: A theory of market equilibrium under conditions of risk. The Journal of Finance, Vol. 19, No. 3, pp. 425-442.

72. Shil N.C., 2009. Performance Measures: An Application of Economic Value Added. International Journal of Business and Management, Vol. 4, No. 3, pp. 169-177.

73. Skantz T.R., Marchesini R., 1987. The effect of voluntary corporate liquidation on shareholder wealth. Journal of Financial Research, Vol. 10, No. 1, pp. 65-75.

74. Stewart G.B., 1990. The Quest for Value: the EVA management guide. Harper Business: New York.

75. Stewart G.B., 1991. The Quest for Value. USA: Harper Collins Publisher, Inc..

76. Sullivan CE., Crutchley D, Johnson, J., 1997. Motivation for voluntary corporate liquidations: Distress, agency conflicts, and shareholder gain. Quarterly Journal of Business and Economics, 36(2), pp. 3-18.

77. Wnuczak P., Mielcarz P., 2009. Wpływ czynników fundamentalnych na kapitalizację spółek giełdowych, Zeszyty Naukowe Uniwersytetu Szczecinskiego. Finanse, Rynki finansowe, Ubezpieczenia, Vol. 17, pp. 275-287.

78. Wnuczak P., 2011. Zastosowanie ekonomicznej wartości dodanej (EVA) w procesie optymalizacji struktury kapitału przedsiębiorstwa. Zeszyty Naukowe Uniwersytetu Szczecińskiego, Finanse, Rynki Finansowe, Ubezpieczenia, Vol. 38, pp. 505-516.

79. Wollny C., 2010. Der objektivierte Unternehmenswert. NWB: Herne.

80. Zarzecki D., 1999. Metody wyceny przedsiębiorstw. Warszawa: Fundacja Rozwoju Rachunkowości.

81. Zarzecki D., Grudziński M., 2010. Standardy wartości stosowane w wycenie przedsiębiorstw. Zeszyty Naukowe Uniwersytetu Szczecińskiego. Finanse, Rynki Finansowe, Ubezpieczenia, Vol. 25, pp. 429-437. 
